\title{
Million Plaque Forming Units
}

National Cancer Institute

\section{Source}

National Cancer Institute. Million Plaque Forming Units. NCI Thesaurus. Code C67268.

A measure of viable infectious entities expressed in millions in the specimen or product defined as the smallest quantity that can produce a cytopathic effect in the host cell culture challenged with the defined inoculum, visible under the microscope or/and to the naked eye as a plaque. 